\title{
ИХ АВРАГЧ НАЙМАН ДАРА ЭХ ДААТГАЛ ШУЛГИЙН ТУХАЙД
}

Д. Сумъяа

\author{
${ }^{l}$ ШУА-ийн Хэл зохиолын хүрээлэн, Монгол улс
} Цахим шуудан: hasaa_11@yahoo.com

Товч агуулга. Энэ өгүҮлэлд "Их аюулаас аврагч найм" (T. 'jigs chen brgyad) бурханы тухай товч тайлбарлаад дараа нь Төвдийн анхдугаар далай лам Гэндэндүв “Сайн зурагт эх” буюу Лэгврима хэмээх магтаал зохиожээ. Энэ зохиолд буй найман их аюулаас авран соёрхохыг хүссэн даатгал шүлэг нь хүний сэтгэлийн гэм хороос зовлон үүдэн гардгийг, эл зовлонгийн найман аюулын ерөндөг даруулга нь сэтгэлийн хорыг дарах нигүүлсэхүй ба оюуны бэлгэ билгүүн болохыг ятган өгүүлсэн болохыг гаргажээ.

Түлхиүр үг. Аврагч найм. Гэндэндүв. Сайн зурагт эх

Бүддийн шашны зан үйлд бүсгүй төрлөөр амьтны тусыг бүтээгч Гэтэлгэгч Дара эх нь үйлсийн бурхан гэх Ногоон Дара эх, насны бурхан Цагаан Дара эх, мөн тус тусын үйлийг даасан Хорин нэгэн дара эх, Энэтхэгээс уламжлалтай найман их аюулаас аврагч найман Дара эх гэж хөгжсөн байдаг.

Энэ найман Дара эх нь Энэтхэгийн бурханы шашны зан үйлд их уламжлалтай. Тиймээс зөвхөн Дара эх бурханд "Их аюулаас аврагч найм" (Т. "jigs chen brgyad) Дара эх гэж байх төдийгүй, Жанрайсаг бурханд мөн найман аюулаас аврагч байна. Ийм найман аюулаас аврагч найман мутарт Жигважаджов бурхан Халх голын баруун хөвөө энгэрт байдаг. Энэ том бурханыг То вангийн ҮҮдэл санаачилгаар 1859-1864 онд бүтээжээ. Учир нь тэр үеийн малчин ардад тохиолдож байсан ган зуд зэрэг байгалын гамшиг болон ирээдүйд учирч болох бүхнээс сэрэмжлэн хамгаалахын тулд энэхүү 8 мутарт Жанрайсиг бурханыг бүтээх нь зүйтэй гэж сонгосон байна.

Найман аюул гэдэг нь:

1. Омогт арслан

2. Мунхаг заан
3. Хилэнт гал

4. Атаархалт могой

5. Муу хулгай

6. Шорон гяндан

7. Далайн давалгаа

8. Махчины аюул юм

Эдгээр нь сэтгэлийн (материаллаг бус) болоод биеийн (бодит) хорлогч хэмээн хоёр байдалтай байна. Учир нь хүмүүн бие болон сэтгэлийн шүтэлцлээр оршдог амьтан. Бие нь орших суурь болж, сэтгэл нь зохилдох шалтгаан болдог.

Биеийн аюул нь арслан, заан, гал, могой, хулгай, ус, шорон гяндан, махчин байдаг. Эд бүгд бодитойгоороо мэдрэгддэг байна. Харин сэтгэлийн аюул нь омог, мунхаг, хилэн, атаархал, муу үзэл, харам, хүсэл тачаал, эргэлзээ эндүү багтдаг байна.

"Хутагт эх Дара эхийн найман аюулаас аврах тогтоол” (Т.: 'phags ma sgrol ma'i 'jigs pa brgyad shyodb kyi gzungs) хэмээхүйд найман их аюулаас аврагч найман Дара эхийн “илт онохуй” хэмээх дүр төрхийг ийн өгүүлжээ.

Баруун тал дахь арслангийн аюулаас аврах Дара эх арслан ханшаарт, соёогоо сайтар ярзайсан, хэл гилбэлгэн мэт 
жилбэлзсэн, шар нүдтэй, хоёр мутартай, улаан өнгөтэй, шар үстэй, зүрхэн тус газраа аймшиггүй өглөгийн мутрын тэмдгийг зохиосон, бүх чимгээр чимсэн эх нь амьтан нугуудыг арслангийн аюулаас гэтэлгэн зохионо.

Зүүн тал дахь зааны аюулаас аврагч Дара эх зааны ханшаарт, нэгэн нигурт, хоёр мутарт, хамар нь өндөр бөгөөд соёо нь ярзайсан, аван идэхийн байдалтай, утааны өнгөт, эрхийгээ илт сунган хоёр мутраараа занан зүхэхийн зохионгуйг үзүүлсэн мутрын тэмдэгт эх нь амьтан нугуудыг зааны аюулаас авран зохионо.

Баруун талын доотод галын аюулаас аврагч Дара эх нь утаан бадарсан ханшаарт, долоон нигуурт, хэлээн хуйлруулсан, үсээн дээшид сэрвийлгэсэн, хоёр мутарт, хоёр мутраар лянхуа цэцгийн мутрын тэмдгийг зохиогоод, чимэг бүгдээр чимсэн эх нь амьтан нугуудыг галын аюулаас гэтэлгэн зохионо.

Зүүн талын доотод могойн аюулаас аврагч Дара эх нь нэг нигуурт, хоёр мутарт, хар өнгөтэй, могойн цогноймол арван толгойт бөгөөд чимэг бүгдээр чимснээр биеийг нь бүтээсэн, хоёр мутраар аймшиггүйн өглөгийн мутрын тэмдгийг зохиосон эх амьтан нугуудыг могойн аюулаас гэтэлгэнэ.

Баруун талаас доод хувьд хулгай дээрмийн аюулаас аврагч Дара эх нэгэн нигурт, хоёр мутарт, биеийн өнгө ногоон, нигур нь уурлан хилэгнэж хунирсан, үсээн дээшид сэрвийлгэсэн, баруун мутраараа илд далайсан, зүүн мутраараа занах хурууг зохиосон, чимэг бүгдээр чимснээр биеийг бүтээсэн эх нь амьтан нугуудыг хулгай дээрмийн аюулаас гэтэлгэнэ.

Зүүн талын доод хувь дор төмөр чөдрийн (шорон гяндан) аюулаас аврагч Дара эх нь нэгэн нигуртай, хоёр мутартай, өнгө цагаан, баруун мутартаа төмөр гох хийгээд цалам барьсан, чимэг бүгдээр чимснээр биеий нь бүтээсэн эх нь амьтнуудыг төмөр чөдрийн аюулаас гэтэлгэн зохионо.

Баруун талын доодын доод хувьд дор усны аюулаас аврагч Дара эх нь нэгэн нигур, хоёр мутартай, биеийн өнгө цагаан, баруун мутартаа төмөр гох хийгээд зүүн мутраараа занах хурууг зохиосон, амирлангуйн бие дүрт эх нь амьтан нугуудыг усны аюулаас гэтэлгэн зохионо.

Зүүн талын доодын доод хувь дор махчны аюулаас аврагч Дара эх нь нэгэн нигур, хоёр мутарт, бодисадуагийн очир завиллаар оршсон, бие нь саран өнгөт, чимэг бүгдээр бичсэн, баруун мутар хийгээд зүүн мутраар дээд өглөг хийгээд аймшиггүй өглөгийн мутрын тэмдгийг зохиосон эх нь амьтан нугуудыг махчны аюулаас гэтэлгэн зохиодог байна.

Анхдугаар далай лам Гэндэндүв (dge 'dun grub. 1391-1474) “Сайн зурагт эх" (legs bris ma) буюу “Дара эхийн магтаал мэргэдийн үснирийн чимэг” хэмээх зохиол бичсэн. Үүндээ Дара эхийг найман аюулаас гэтэлгэхийг хүсэн даатгажээ. Өөрөөр хэлбэл хүний сэтгэлийн гэм нүгэл, түүнээс үүдэн төрөх найман зовлонгоор шаналах түүнээс гэтэлгэн энэрэхийг даатгажээ. Энэ “Сайн зурагт эх" зохиолын тухай Алшаа Дандар лхарамба “Дара эхийн магтаал мэргэдийн зулайн чимгийн тийн номлол мэргэдийн орой дахь эрдэнэ шигтгэсэн чимэг" (sgrol bstod mkhas ba'i gtzug rgyan gyi rnam pshad mkhas pa'i gtzug nor gyi phra rgyan ces bya ba bzhugs so) хэмээх тайлбар зохиол бичсэн байна. Гэндэндүвийн “Сайн зурагт эх” даатгал шүлгийн утгыг дээрх тайлбараар дэлгэрүүлж үзвэл:

T.; 'jigs tsogs lta ba'i ri sul gnas bcas te// gzhan las mchog tu 'dzin pas sems khengs shing//

pha rol khyad du gsod pa'i sbar khyim can//

nga rgyal seng ge'i 'jigs pa bskyabs du $\mathrm{gsol} / /$

(1. 216-р нүYр)

M.;ebederk yinci@ul@an j 1- n a@ulayin qonggil dur oron jascu:

busud-aca deged bolu@ad bariqui-bar sedkilomo@si@ad:

cinadus-i le to@aqu sarba@utu: 
omu@-tu arslan-u ayul-i aburan soyurq-a:

(2. 4a нүYр)

Эвдрэхүйн чуулган үзлийн уулын

хонгил дор орон засч

Бусдаас дээд болоод барихуй бээр

сэтгэл омогшоод

Чинадасыг үл тоох сарвуут

Омогт арслангийн аюулыг авран соёрх

- гэж байна.

Энд бусдыг үл тоон, биеэ өргөсөн бардам сэтгэлийг омогт арслангаар үлгэрлэжээ. Арсланд бусдыг үл тоох хүчит сарвуу бий. Хүмүүнд түүн шиг үл тоох омогт сэтгэл төрнө. Хүчит сарвуундаа эрдсэн арслан юу ч хүрч чадахгүй өндөр уулын халил хонгилд орныг засдаг шиг бусдыг үл тоох омогт сэтгэл нь мөн хөндий хоосон үзлийн хонгилд орогнодог гэж эл үлгэрээр гаргажээ.

T.; dran shes lcags kyu rnon pos ma btul zh-

ing//

'dod yon myos chu 'thungs pas 'thoms

pa'i mthus//

log pa'i lam zhugs gnod 'tse'i mche ba

gtzigs//

gti mug glang bo'i 'jigs pa bskyab du $\mathrm{gsol} / /$

(1. 216-р нүур)

M.;duradin medek yin qurca@oq-a bar ese nomqa@du@ad:

k $\sim$ sel- n erdem- n arkin-i uu@uqui-bar

sarina@san k c $\sim$ n-iyer:

buru@u m`r-d r oron qoor k’n gel- n

soyu@-a irjayi@san:

mungqa@-unja@an-u ayul-i aburan

soyurq-a:

(2. 4a нүYр)

Дурдан мэдэхүйн хурц гохоор эс номхтогдоод

Хүслийн эрдмийн архийг уухуйгаар

сарнисан хүчнээр

Буруу мөр дор орон хор хөнөөлийн

соёог ярзайлгасан

Мунхагийн зааны аюулыг авран соёрх -

гэжээ.
Энд зааныг хурц гохоор номхотгон, ачлага уналганд хэрэглэдэг. Гэтэл тэр хурц гохгүй галзуурсан заан хавийн газрыг тэр гэхийн тэмдэггүй болтол эвдэж сүйтгэдэг. Үүн шиг ухаан билгээр өөрийн мунхаг сэтгэлийг эс номхотгоод, хүслийн архиар согтуурсан нь, сэтгэл мэнэрэн галзуурч араа шүдээ ярзайлгасан заан лугаа адил тул хор хөнөөл хэрүүл тэмцэл өдөөх аюулыг бий болгоно. Зааныг хурц гохоор номхотгодог, сэтгэлийн мунхгийг ухаанаар номхотгодог гэжээ.

T.: tsul min yid byed rlung gis bskul ba las// nyes spyod dud sprin 'khrigs pa'i klong dkyil na//

dge ba'i nags tsal sreg pa'i nus pa can// zhe sdang me yi 'jigs pa bskyab du gsol//

(1. 216-р нүур)

M.:yoson busu-yi sedkin $\sim$ yiledk $\sim$ kei-ber k'delgegsen-ece:

gem-t $\sim$ yabudal-un uta $@$ a eg len yimcigsen $t^{\prime} b-d \sim r$ :

buyan-u oi cecerlig-i t $\sim$ yimerdek $\sim$-yin cidal-tu:

urin-u@al-un ayul-i aburan soyurq-a:

(2. 4а нүүр)

Ёсон бусыг сэтгэн үйлдэх хийгээр

хөдөлгөснөөс

Гэмт явдлын утаа үүлэн үймцсэн төвд

Буяны ой цэцэрлэгийг түймэрдэхийн чадалт

Урины галын аюулыг авран соёрх - гэж байна.

Энд хилэнт улаан түймрийн гал юуг ч үл хайрлан үзсээр харсаар байтал бүхнийг өрөвхийн түймэрдэн алга хийдэг. Үүн шиг уур хилэнгийн мунхаг сэтгэл нь бас бүтэж байсан үйл, бүтэн байсан орчлонг эвдэн бусниулахын утга, галаар хөшиглөн нөмрөхийн үлгэр нэгэн гэжээ. Иймд уур хилэнгийн мунхаг сэтгэл нь нэгэн нас төдийгүй, хэдэн үе насандаа хураасан зөв сайны үйлс, өөрөөр хэлбэл “буяны ойн цэцэрлэгийг” түймэрдэн, сэтгэл болон ухааныг нүдийг харанхуйлан хаана хэмээжээ. 
T.: ma rig thibs po'i khung du mngon zhen cing//

gzhan 'byor phun tsogs mthong tse mi bzod par/l

gdug pa'i dug gis myur du khyab byed pa'i//

phrag dog sbrul gyi 'jigs pa bskyab du $\mathrm{gsol} / /$

(1. 216-217-р нүYр)

M.:mingqa@-un b rk $\sim$ g n ken-d $\sim$ r ilete sinu@ad:

busud-un olburi qotala teg $\sim$ S $\sim$ gsen- $~$

>jek yin ca@-dur 1 tes n:

qoor-tan-u qoor-a-bar t $\sim$ rgen-e $\mathrm{t} \sim \mathrm{g} \sim$ gci

nayidang@ui mi@ai-yin ayul-i aburan

soyurq-a

(2. 4a нүур)

Мунхагийн бүрхэг нүхэн дор илт

шунаад

Бусдын олбор хотол төгссөнг үзэхүйн

цагт үл тэсэн

Хортоны хороо түргэнээ түгээгч

Найдангуй могойн аюулыг авран соёрх

- гэж байна.

Хорт могой харанхуй нүхэнд оршдог. Харин нүхнээс гарвал өөртөө тааралдсан хэн юу бүхнийг хэлээ улбалзуулан хатгаж, аймшигт хороороо хордуулан хөнөөнө. Түүн лүгээ адил ухааны гэгээрлийг олоогүй хүмүүн мунхагийн харанхуй нүхний хорт могой мэт найдангуй атаат сэтгэл бусдын ажил үйлсийн өөдрөг дэлгэр явааг үзэнгүүт тэвчиж тэсэн үл ядаж хорлох хөнөөгдөхийн хор нь арвиддагийг хорт могойн аюулаар үлгэрлэжээ.

T.: brdul zhugs dman pa'i 'brog dgon 'jigs rung dang//

rtag cad mya ngam thang la rab rgyu zhing//

phan bde'i grong dang dgon pa kun 'joms pa'i//

lta ngan rkun po'i 'jigs pa bskyabs du $\mathrm{gsol} / /$

(1. 217-p нүур)

M.:t`r yosun door-a-du-yin k'dege a@la@unayu@umsi@ba: m`ngke tasurqai@asalang-un tala-dur masida g yiged:

tusa jir@alang-unbal@ad kiged keyed b k n-idaru@ci:

ma@uqula@ai-yin ayul-i aburan soyurq-a:

(2. 4a нүYр)

Төр ёсон доордын хөдөө аглагийн аюумшиг ба

Мөнх тасархай гаслангийн тал дор машид гүйгээд

Тус жаргалангийн балгад хийгээд хийд бүхнийг дарагч

Муу хулгайн аюулыг авран соёрх - гэж байна.

Хулгайч хүмүүн хол хөдөө, хээр аглагт орогноод, айл орон, хот балгадыг сүйдлэн дээрэмдэх мэт, муу үзлийн сэтгэл бол тэрхүу хулгайчтай адил төр ёсон үгүй доордын оюунд орогнож мөнхдөх тасархайтах хоёр туйлшралын цөлийдөлд автан, “буй”, “үгүй” хоёр хэтийдлийн “гаслант талд” гүйж, тус жаргалангийн зөв сайны үзэлтээс зугтаалгадаг тул муу үзлийн хулгайчийг сэтгэлд орж ирэхээс сайтар хурдан сэргийлэхийг ухуулжээ.

T.: mi bzad srid pa'i brtzon khang ra ba ru//

lus can rang dbang med par 'cang byed cing//

sred pa'i sgo lcags dbye dkas 'khyad pa yi//

ser sna'i lcags sgrog 'jigs pa bskyabs du gsol//

(1. 217-р нүур)

M.:tesdesi $\sim$ gei sansar-un gindan-u k riyen$\mathrm{d} \sim \mathrm{r}$ :

biy-e-ten `ber $\sim$ n erke $\sim$ geg $\sim$ i-e k ligdeged:

qurical-un eg den-i tem r ci@ur@-a-bar ci@ura@la@san:

qaram-un tem $\sim$ r cider- $\sim$ n ayul-i aburan soyurq-a:

$$
\text { (2. 4a-4б нүур) }
$$

Тэсдэш үгүй сансрын гянданы хүрээн дор

Биетэн өөрийн эрх үгүйеэ хүлэгдээд Хурьцалын үүднийг төмөр цуургаар 
цуургаласан

Харамын төмөр чөдрийн аюулыг авран coёрx - гэж байна.

Энэ нь биетэн өөрийн эрх бүгдийг алдан гянданд хоригдон хашигддаг. Үүний үлгэрээр угтаа хүмүүн өөрийн сэтгэлийн эрхийг өөрөө цоожлон, өөрөө хорьж, бусдаас сэтгэл болон сэтгэлийн өглөг харамлан суухыг харам сэтгэлийн чөдөр хэмээжээ.

T.: shin du brgal dka' srid pa'i rgyun phyogs

khyer//

las rlung drag po'i rkyen dang nye ba las// skye rga na 'chi'i rba klong rab 'khrug pa'i//

'dod chags chu bo'i 'jigs pa bskyab du $\mathrm{gsol} / /$

\section{(1.217-p нүур)}

M.:masida get $\sim 1 k \sim y-e$ berke sansar-un urus@ al-un j j-d r abtan:

>yile- n do@sin kei-yin n`g cel l ge oyiratu@san-aca:

t’r k `telk i ebedk i k k - yin dabal@a sayitur $\sim$ yimecegsen:

taciyang@u-yin m’ren- ayul-i aburan soyurq-a:

(2. 46 нүур)

Машид гэтлэхүйеэ бэрх сансрын

урсгалын зүгт автан

Үйлийн догшин хийн нөхцөл лүгээ

ойртсоноос

Төрөх, өтлөх, өвдөх, үхэхүйн давалгаа сайтар үймцсэн

Тачаангуйн мөрний аюулыг авран соёрх - гэж байна.

Живүүлэхийн аймшиг үймцсэн их далай мөрний урсгалд автан сөрөн сэлэхийн тэнхэл тасарсан нэгэнд үйлийн догшин нөхцөл ойртон ирсэн нь эргэлзээгүй. Үүн лүгээ адил төрөх, өтлөх, өвдөх, үхэхийн тавилант амьдралын мөрөнд хүмүүн олныг урсгагч хүсэл шуналыг мөрний их аюулаас аврахыг гуйжээ. Энд далай мэт хэмжээгүй шуналын гэмийг эс боосноос төрөх, өтлөх, өвдөх, үхэхийн дөрвөн далайн зовлонд хүргэдэг хэмээж, тачаангуй хурьцлын усан мөрний үргэлжлэлийг таслахыг номложээ.

T.: kun du rmongs pa'i mkha' la rab rgyu zhing//

nges pa dong du gnyer la lhag par 'tse// thar ba'i srog la rgol ba'i gdug pa can// the tsom sha za'i 'jigs pa bskyabs du gsol//

$$
\text { (1. 217-p нүYр) }
$$

M.:b k n-e mungqara@san o@tar@ui-dur masi g yiged:

ma@ad ut@-a-yi egeregci-d r r lemji-t

k'n gen:

tonilaquyin amin-dur eserg $\sim$ lek $\sim$ yin qoortu:

sesig-t $\sim$ biseci-yin ayul-i aburan soyurq-a:

(2. 46 нүур)

Бүхнээ мунхарсан огторгуй дор маш гүйгээд

Магад утгыг эгээрэгч дор үлэмжид хөнөөн

Тонилохуйн амин дор эсэргүйлэхүйн хорт

Сэжигт бичэсийн аюулыг авран соёрх гэж байна.

Энд эргэлзээ сэжигт сэтгэлийг махчинтай зүйрлэсэн байна. Учир нь эргэлзээ сэжит сэтгэл нь үнэн зөвийг тунгааж олохын оронд, харин түүнээс гэм сэжигтэнг эрдэг тул үнэн магадыг хөнөөгч юм. Эргэлзээ сэтгэл нь харанхуй буюу ухаангүй балайд шүтэн төрдөг учир зөв оюуныг хорлон хөнөөх хоёр үзүүртэй сэтгэл учраас түүнийг махчинтай зүйрлэжээ.

Ийн Гэндэндүвийн “Сайн зурагт эх" буюу Лэгврима хэмээх магтаалд буй найман их аюулаас авран соёрхохыг хүссэн даатгал шүлэг нь хүний сэтгэлийн гэм хороос зовлон үүдэн гардгийг, эл зовлонгийн найман аюулын ерөндөг даруулга нь сэтгэлийн хорыг дарах нигүүлсэхүй ба оюуны бэлгэ билгүүн болохыг ятган өгүүлсэн байна. 


\section{Аиигласан бүтээлтийн жагсаалт}

1. Legs bris ma bzhugs so. Bstog smon phyogs bsgrigs mtso sngon mi rigs dpe skran khang. 1993.

2. Sen ldin-un Dda-ri eke kemegdek orosiba. Бар $29 \times 8,5$ cм. Хуyдac 6

3. Богд Зонхаба. “Бодь мөрийн зэрэг” (иинэ үсгээр). Орчуулсан бурханч лам Г.Пүрэвбат, $2002 \mathrm{oн}$

4. Буддын шашин, соёльн тайлбар толь. I, ІІ дэвтэр. УБ. 2000 он

5. Бүрнээ Д, Энхтөр Д. “Төвд Монгол илт өгҮҮлэхийн нэрийн толь”, УБ. 2003 он

6. Дээд тойн гэтэлгэгч Дарь эхийн магтаал, хорин нэгэн мөргөлийн номлол найруулал, нүҮрлэсэн аюулыг нэн ялсан магнаг дуаз хэмээгдэгч оршвай. Орчуулсан Бат.Идэрбаяр, Улаанбаатар, 98 хуудас. 2002 он

7. Түргэн авралт Дар-эх. Төвд хэлнээс орчуулсан С.Мөнхтайван. УБ. 2010 он

8. Сумъяа Д. Дара эхийн магтаалын нээх утга. Улаанбаатар, 2002 он

9. ХУрэлбаатар Л. Судар шастирын билиг. Улаанбаатар, 2002 он

10. Цэрэнсодном Д. Монгольн бурханы шашны уран зохиол. УБ. 1997 он

11. Монгол түмний их шүтээн Жигважаджов Жанрайсиг бурхан. Эрдэм шинжсилээний бага хурлын материал. 2011 он 